Western New England University School of Law Digital Commons @ Western New England University School of Law

2017

\title{
Blatt v. Cabela's Retail, Inc. and a New Path for Transgender Rights
}

Kevin M. Barry

Quinnipiac University School of Law, kevin.barry@quinnipiac.edu

Jennifer L. Levi

Western New England University School of Law, jlevi@law.wne.edu

Follow this and additional works at: http:// digitalcommons.law.wne.edu/facschol

Part of the Disability Law Commons, and the Law and Gender Commons

\section{Recommended Citation}

Kevin Barry \& Jennifer Levi, Blatt v. Cabela's Retail, Inc. and a New Path for Transgender Rights, 127 YALE L.J. F. 373 (2017).

This Article is brought to you for free and open access by the Faculty Publications at Digital Commons @ Western New England University School of Law. It has been accepted for inclusion in Faculty Scholarship by an authorized administrator of Digital Commons @ Western New England University School of Law. For more information, please contact pnewcombe@law.wne.edu. 
THE YALE LAW JOURNAL FORUM

OCTOBER 12,2017

\section{Blatt v. Cabela's Retail, Inc. and a New Path for Transgender Rights}

Kevin Barry and Jennifer Levi

A B S TRACT. Since the Supreme Court recognized marriage equality in Obergefell $v$. Hodges, civil rights advocates have increasingly set their sights on transgender rights as the next legal frontier. Sex discrimination law, though an essential statutory tool, is not the only potential avenue for securing rights for transgender individuals. Another important federal source of protection for transgender people is disability rights law -in particular, the Americans with Disabilities Act (ADA). Disability rights law, unlike sex discrimination law, applies to public accommodations and government services, and also mandates reasonable accommodations. A transgender litigant successfully invoked the protections of the ADA for the first time in the recent case of Blatt v. Cabela's Retail, Inc., where a federal court ruled that transgender people are not categorically barred from seeking relief under the ADA from discrimination based on gender dysphoriathe clinically significant distress that some transgender people experience. Importantly, the Department of Justice under both the Obama and Trump Administrations has similarly interpreted the ADA to cover such discrimination. This Essay explores why, for over twenty-five years, transgender litigants have not invoked the protections of the ADA-and why they now should. Blatt's historic holding will reverberate beyond the facts of that case, setting the stage for ADA challenges to a broad range of discrimination against transgender people who experience stigma and bias associated with gender dysphoria.

Since the Supreme Court's historic decision recognizing marriage equality in Obergefell v. Hodges, ${ }^{1}$ transgender rights have quickly emerged as one of the

1. 135 S. Ct. $2584,2604-05$ (2015). 
most important frontiers for civil rights. ${ }^{2}$ Transgender individuals' access to appropriate gender-segregated facilities, particularly restrooms, has taken center stage in this debate. ${ }^{3}$ On April 19, 2016, in G.G. ex rel. Grimm v. Gloucester County School Board, the Fourth Circuit became the first federal court of appeals to rule that Title IX of the Education Amendments of 1972 prohibits a school from excluding a transgender boy from the boys' student restroom, relying on agency guidance issued by the Obama Administration. ${ }^{4}$ Although the Supreme Court vacated the Fourth Circuit's judgment after the Trump Administration rescinded that guidance, ${ }^{5}$ other federal courts appear poised to reach the same conclusion on other grounds. The Seventh Circuit, which recently upheld a preliminary injunction allowing a transgender boy to use the boys' student restroom at his school, noted that the court was "not alone in [its] belief" that Title IX encompasses discrimination against transgender people. ${ }^{6}$

2. See Scott Skinner-Thompson, How Obergefell Could Help Transgender Rights, SLATE (June 26, 2015, 2:26 PM), http://www.slate.com/blogs/outward/2015/o6/26/obergefell _and_trans_rights_the_supreme_court_s_endorsement_of_identity.html [http://perma.cc $\left./ \mathrm{JY}_{5} \mathrm{~B}-\mathrm{V}_{7} \mathrm{H}_{9}\right]$.

3. Understanding Transgender Access Laws, N.Y. TiMES (Feb. 24, 2017), http://www.nytimes .com/2017/o2/24/us/transgender-bathroom-law.html [http://perma.cc/2JZ2-9HHA].

4. G.G. ex rel. Grimm v. Gloucester Cty. Sch. Bd., 822 F.3d 709, 715 (4th Cir. 2016), cert. granted in part, 137 S. Ct. 369 (2016), and vacated and remanded, 137 S. Ct. 1239 (2017).

5. Gloucester Cty. Sch. Bd. v. G. G. ex rel. Grimm, 137 S. Ct. 1239 (2017); see also U.S. Dep't of Justice, Civil Rights Div. \& U.S. Dep't of Edu., Dear Colleague Letter on Transgender Students (Feb. 22, 2017), http://www2.ed.gov/about/offices/list/ocr/letters/colleague-201702 -title-ix.docx [http://perma.cc/RUZ3-LTMS] (withdrawing and rescinding the Obama Administration guidance). On October 4, 2017, the Trump Administration likewise withdrew guidance issued by the Obama Administration that interpreted Title VII of the Civil Rights Act of 1964 to prohibit employment discrimination based on gender identity per se, including transgender status. Compare Memorandum from the U.S. Att'y Gen'l to U.S. Att'ys on Revised Treatment of Transgender Discrimination Claims Under Title VII 2 (Oct. 4, 2017), http://assets.documentcloud.org/documents/4067437/Sessions-memo-reversing -gender-identity-civil.pdf [http://perma.cc/Y6JK-B4UK] (withdrawing Obama Administration guidance), with Memorandum from the U.S. Att'y Gen'l to U.S. Att'ys on Treatment of Transgender Employment Discrimination Claims Under Title VII 1 (Dec. 15, 2014), http://www.washingtonblade.com/content/files/2014/12/Title-VII-Memo .pdf [http://perma.cc/5JZ2-MJQZ] (interpreting Title VII to prohibit "discrimination based on gender identity in and of itself"). Here, as in the Title IX context, the weight of judicial authority is against the Trump Administration's interpretation. See infra note 6 and accompanying text.

6. Whitaker v. Kenosha Unified Sch. Dist., 858 F.3d 1034, 1048-49 (7th Cir. 2017) (discussing the decisions of two other circuit courts, the Eleventh and Sixth Circuits, and six district courts that concluded that discrimination against transgender people constitutes sex discrimination in violation of Title VII of the Civil Rights Act and other sex antidiscrimination statutes); see also Examples of Court Decisions Supporting Coverage of LGBT-Related Discrimi- 
The legal issue at the heart of these cases centers on whether federal sex discrimination law fully extends to transgender students. Does Title IX (and, by extension, Title VII of the Civil Rights Act and other federal laws prohibiting sex discrimination) provide comprehensive equality guarantees to transgender individuals, as Gavin Grimm argues?7 Or do cultural and societal norms regarding gender justify gaps in the laws' coverage? ${ }^{8}$

These are important questions for transgender rights. Although sex discrimination law is an essential statutory tool for securing transgender rights, it is not the only one. Disability rights law - which, unlike sex discrimination law, applies to public accommodations and government services, and also mandates reasonable accommodations - is another important federal source of protection for transgender people. ${ }^{9}$ In particular, the Americans with Disabilities Act of 1990 ("ADA"), which prohibits discrimination based on "disability" in a broad range of public and private settings, ${ }^{10}$ has profound implications for the advancement of transgender rights. In a recent landmark case, Blatt v. Cabela's Retail, Inc., ${ }^{11}$ a federal court ruled for the first time that transgender people are not categorically barred from seeking relief from discrimination under the ADA. Importantly, the Department of Justice under both the Obama and Trump Administrations has similarly interpreted the ADA to cover such discrimination. ${ }^{12}$

nation Under Title VII, EQUAL EMP. OPPORTUNITY COMMISSION, http://www.eeoc.gov/eeoc /newsroom/wysk/lgbt_examples_decisions.cfm [http://perma.cc/JL $3 \mathrm{H}-\mathrm{MQX}_{3}$ ] (compiling federal court decisions supporting coverage for transgender individuals as sex discrimination).

7. See G.G., 822 F.3d at 718-19 (discussing plaintiff's argument that court should give controlling weight to the 2015 Department of Education opinion letter stating that " $[\mathrm{w}]$ hen a school elects to separate or treat students differently on the basis of sex . . . a school generally must treat transgender students consistent with their gender identity").

8. See $i d$. at 721 (discussing the view that "maleness and femaleness [a]re determined primarily by reference to the factors the district court termed 'biological sex,' namely reproductive organs").

9. $\quad 42$ U.S.C $\$ 12101$ et seq. (2012).

10. Id.

11. Blatt v. Cabela's Retail, Inc., No. 5:14-CV-04822, 2017 WL 2178123 (E.D. Pa. May 18, 2017).

12. Compare Second Statement of Interest of the United States at 5, Blatt, 2017 WL 2178123 (E.D. Pa. Nov. 16, 2015) (No. 5:14-CV-04822) [hereinafter Second Statement] ("In light of the evolving scientific evidence suggesting that gender dysphoria may have a physical basis, . . . the GID Exclusion should be construed narrowly such that gender dysphoria falls outside its scope."), with Statement of Interest of the United States at 3, Doe v. Arrisi, No. 3:16-CV-o8640 (D.N.J. July 17, 2017) ("[B]ecause Plaintiff has alleged that her [Gender Dysphoria] resulted from a 'physical impairment,' . . . by definition she has alleged that she falls within the statutory protections of the ADA."). 
This Essay explores why, for over twenty-five years, transgender litigants have not invoked the protections of the ADA-and why they now should. In Part I, the Essay discusses the ADA's morality-driven exclusion of three conditions associated with transgender people, and how this exclusion has led transgender litigants to eschew disability rights law in favor of sex discrimination protections. In Part II, we turn to Blatt v. Cabela's Retail, Inc. ${ }^{13}$ in which the court held that gender dysphoria-the clinically significant distress that some transgender people experience ${ }^{14}$ - constitutes a protected disability under the ADA. We also discuss well-intentioned but misguided concerns regarding ADA coverage of gender dysphoria, and why the consensus of the transgender rights community is firmly in support of such coverage. In Part III, this Essay traces a new path forward for transgender rights after Blatt: disability rights protection for transgender people who experience stigma and bias associated with gender dysphoria, including a lack of access to appropriate bathrooms for transgender students, ${ }^{15}$ refusal of proper uniforms to transgender workers ${ }^{16}$ denial of access to proper medical care and gender-appropriate facilities and programs to transgender prisoners, ${ }^{17}$ and threats of exclusion of transgender patrons from private business establishments. ${ }^{18}$

13. Blatt, 2017 WL 2178123.

14. Am. Psychiatric Ass'n, Diagnostic and Statistical Manual of Mental Disorders 45153 (5th ed. 2013) [hereinafter DSM-5].

15. See, e.g., Gavin Grimm, Opinion, Gavin Grimm: The Fight for Transgender Rights Is Bigger Than Me, N.Y. TiMES (Mar. 7, 2017), http://www.nytimes.com/2017/o3/o7/opinion/gavin -grimm-the-fight-for-transgender-rights-is-bigger-than-me.html [http://perma.cc/824E $-\mathrm{G}_{57 \mathrm{Z}}$ ] (discussing the school's refusal to permit transgender student to use genderappropriate bathrooms).

16. See, e.g., Kevin Barry \& Jennifer Levi, A Landmark Victory for Trans Rights-Under the Americans with Disabilities Act, SLATE (May 24, 2017, 12:27 PM) http://www.slate.com/blogs /outward/2017/05/24/a_landmark_victory_for_trans_rights_under_the_ada.html [http:// perma.cc/3 $\mathrm{EK}_{3}-\mathrm{GJTD}$ ] (discussing a lawsuit challenging, inter alia, employer's refusal to provide transgender employee with gender-appropriate uniform).

17. See infra note 87 and accompanying text (discussing a lawsuit brought by formerly incarcerated transgender woman challenging, inter alia, solitary confinement in a genderinappropriate facility, incorrect name and pronoun usage, and denial of access to genderappropriate programs, clothing, and accessories).

18. See, e.g., Eliott C. McLaughlin, North Carolina's HB142: Repeal? Compromise? What Does It All Mean?, CNN (Mar. 30, 2017), http://www.cnn.com/2017/o3/30/us/north-carolina-hb2 -repeal-hb142-explainer [http://perma.cc/6W92-NLUJ] (discussing North Carolina's House Bill 2 and its replacement law, HB 142, which, among other things, prohibit local governments from protecting transgender people from discrimination in public accommodations). 


\section{SEX AND DISABILITY}

As clarified by the 2008 amendments to the ADA, ${ }^{19}$ the statutory definition of disability is extremely broad and, frankly, a misnomer. The word "disability" is commonly associated with medical conditions that disrupt a person's ability to function - that incapacitate. ${ }^{20}$ Indeed, that is exactly how "disability" is defined in the Social Security Act, which provides cash benefits to people with medical conditions who cannot work because of those conditions. ${ }^{21}$ Under the $\mathrm{ADA}$, however, disability means something very different. A person is covered by this law if the person is discriminated against based on a real or perceived medical condition - regardless of how limiting that condition may be. ${ }^{22} \mathrm{~A}$ person is also covered if the person has or once had a medical condition that would, in the absence of treatment, be substantially limiting. ${ }^{23}$

To illustrate the breadth of the ADA's coverage, consider a person who successfully manages depression with medication and talk therapy, a person with epilepsy who has been seizure-free for decades, a person with diabetes who takes insulin, a person with an anxiety disorder who avoids certain social situations, and a person undergoing surgery for a back injury. They are all covered by the ADA regardless of how or whether their medical condition actually interferes with activities of daily living. ${ }^{24}$

19. ADA Amendments Act of 2008, Pub. L. No. 110-325, 122 Stat. 3553.

20. See, e.g., Chai R. Feldblum, Definition of Disability Under Federal Anti-Discrimination Law: What Happened? Why? And What Can We Do About It?, 21 Berkeley J. EMP. \& LAB. L. 91, 140 (200o) ("In the area of disability, the instinctive understanding displayed by most courts is that 'disability' is synonymous with 'inability to work or function,' and that people with disabilities are significantly different from the norm.”).

21. See 42 U.S.C. $\mathbb{S} 423(\mathrm{~d})(1)(\mathrm{A})$ (2012) (“The term 'disability' means . . . inability to engage in any substantial gainful activity by reason of any medically determinable physical or mental impairment which can be expected to result in death or which has lasted or can be expected to last for a continuous period of not less than 12 months.").

22. See 42 U.S.C. $\$ 12102(3)(A)$ (2012) ("An individual meets the requirement of 'being regarded as having such an impairment' if the individual establishes that he or she has been subjected to an action prohibited under this chapter because of an actual or perceived physical or mental impairment whether or not the impairment limits or is perceived to limit a major life activity.").

23. See id. $\mathbb{S S}$ 12102(1), (4)(E)(i) (stating that " $[\mathrm{t}]$ he term 'disability' means, with respect to an individual - (A) a physical or mental impairment that substantially limits one or more major life activities of such individual" and "(B) a record of such an impairment," and that " $[t]$ he determination of whether an impairment substantially limits a major life activity shall be made without regard to the ameliorative effects of mitigating measures").

24. See 29 C.F.R. $\mathbb{S} 1630.2$ (2016) ("II]t should easily be concluded that the following types of impairments will, at a minimum, substantially limit the major life activities indicat- 
According to his complaint, Gavin Grimm was "diagnosed by medical professionals as having Gender Dysphoria, which is a serious medical condition characterized by clinically significant distress caused by an incongruence between a person's gender identity and the person's assigned sex at birth." ${ }^{25}$ Left untreated, gender dysphoria can result in debilitating depression, anxiety, and, for some people, suicidality and death. ${ }^{26}$ As part of his medically-supervised treatment for gender dysphoria, Grimm underwent hormone therapy, legally changed his name, and lived "as a boy in all aspects of his life," including, naturally, using the boys' restroom. ${ }^{27}$

Though not pleaded in Grimm's complaint, the ADA might have provided a source of relief separate from Title IX. Under the ADA, Grimm could have alleged that the school board's policy denied him equal access to benefits provided to his peers who did not have gender dysphoria - namely, the ability to use the boys' restroom. ${ }^{28} \mathrm{He}$ might also have alleged that the policy had a discriminatory effect on boys with gender dysphoria, singling them out by requiring

ed: . . . diabetes substantially limits endocrine function; epilepsy substantially limits neurological function; . . . and major depressive disorder, bipolar disorder, posttraumatic stress disorder, obsessive compulsive disorder, and schizophrenia substantially limit brain function."); Jacobs v. N.C. Admin. Office of the Courts, 780 F.3d 562, 573-74 (4th Cir. 2015) (holding that the plaintiff's social anxiety disorder was a disability under the ADA, even though the plaintiff "interact[ed] with others on a daily basis, routinely answered inquiries from the public at the front counter, socialized with her co-workers outside of work, and engaged in social interaction on Facebook" (internal quotation marks omitted)); Mazzeo v. Color Resolutions Int'l, LLC, 746 F.3d 1264, 1269-70 (11th Cir. 2014) (holding that the plaintiff's back injury was a disability under the ADA when considered without regard to the ameliorative effects of back surgery).

25. Complaint at 1, ๆ 1, G.G. ex rel. Grimm v. Gloucester Cty. Sch. Bd., 132 F. Supp. 3d 736 (E.D. Va. 2015) (No. 4:14-CV-ooo54-RGD-TEM) [hereinafter G.G. Complaint].

26. See DSM-5, supra note 14 , at 454-55; Brief of Amici Curiae Gay \& Lesbian Advocates \& Defenders et al. in Opposition to Defendant's Partial Motion to Dismiss at 7, Blatt v. Cabela's Retail, Inc., No. 5:14-CV-4822-JFL, 2017 WL 2178123 (E.D. Pa. Feb. 23, 2015) [hereinafter Blatt Amicus Brief].

27. G.G. Complaint, supra note $25, \boldsymbol{\Upsilon}$ 2, 26.

28. See 28 C.F.R. $\mathbb{S} 35.130(\mathrm{~b})(\mathrm{1})(\mathrm{i})-(\mathrm{ii}),(\mathrm{b})(\mathrm{1})(\mathrm{iv})$, (d) (2016) (prohibiting "[d]eny[ing] a qualified individual with a disability the opportunity to participate in or benefit from the aid, benefit, or service"; "afford[ing] a qualified individual with a disability an opportunity to participate in or benefit from the aid, benefit, or service that is not equal to that afforded others"; "[p]rovid[ing] different or separate aids, benefits, or services to individuals with disabilities or to any class of individuals with disabilities than is provided to others"; and failing to "administer services, programs, and activities in the most integrated setting appropriate to the needs of qualified individuals with disabilities"). 
that they - and no one else-use a separate, non-student-use restroom. ${ }^{29}$ Lastly, he might have argued that the school had a duty to modify its restroom policy to ensure that transgender boys can use the boys' restroom and that such a modification would not "fundamentally alter" the educational services provided by the school. ${ }^{30}$

Gavin Grimm likely did not allege discrimination under the ADA for a simple reason: the ADA explicitly excludes "transvestism, transsexualism ... . [and] gender identity disorders not resulting from physical impairments." ${ }^{31}$ The legislative history of the ADA reveals that these three conditions were excluded due to congressional moral opprobrium, including and especially that of two conservative senior senators, William Armstrong (R$\mathrm{CO}$ ) and Jesse Helms (R-NC). ${ }^{32}$ In support of his proposed amendment ex-

29. See id. $\mathbb{S} 35 \cdot 13 \mathrm{o}(\mathrm{b})(3),(\mathrm{b})(3)(\mathrm{i}),(\mathrm{b})(8)$ (prohibiting a public entity from "utiliz[ing] criteria or methods of administration . . . that have the effect of subjecting qualified individuals with disabilities to discrimination on the basis of disability," and "apply[ing] eligibility criteria that screen out or tend to screen out an individual with a disability or any class of individuals with disabilities from fully and equally enjoying any service, program, or activity").

30. See id. $\$ 35.130(\mathrm{~b})(7)$ ("A public entity shall make reasonable modifications in policies, practices, or procedures when the modifications are necessary to avoid discrimination on the basis of disability, unless the public entity can demonstrate that making the modifications would fundamentally alter the nature of the service, program, or activity.").

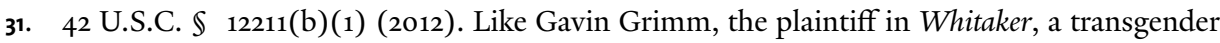
boy "diagnosed . . . with Gender Dysphoria," brought claims against his school district under Title IX and the Equal Protection Clause - but not under the ADA. Whitaker v. Kenosha Unified Sch. Dist., 858 F.3d 1034, 1040 (7th Cir. 2017) (affirming the district court's preliminary injunction against the school district).

32. See Kevin M. Barry, Disabilityqueer: Federal Disability Rights Protection for Transgender People, 16 Yale Hum. RTS. \& DeV. L.J. 1, 13-25 (2013) (discussing the legislative history of the ADA). For several foundational articles discussing the legislative history behind the ADA exclusions, see Christine Michelle Duffy, The Americans with Disabilities Act of 1990 and the Rehabilitation Act of 1973, in GENDER IDENTITY AND SEXUAL ORIENTATION DISCRIMINATION IN the WorkPlace: A Practical Guide 16-42 (Christine Michelle Duffy et al. eds., 2014); Kevin M. Barry et al., A Bare Desire To Harm: Transgender People and the Equal Protection Clause, 57 B.C. L. Rev. 507, 526-40 (2016); Ruth Colker, Homophobia, AIDS Hysteria, and the Americans with Disabilities Act, 8 J. GENDER, RACE \& JUST. 33, 44-46, 49-50 (2004). See also Robert L. Burgdorf, Jr., The Americans with Disabilities Act: Analysis and Implications of a Second-Generation Civil Rights Statute, 26 HARV. C.R.-C.L. L. ReV. 413, 519 (1991) ("No evidence suggests that Congress investigated such conditions, except, perhaps, for the problem of illegal drug use. Consequently, it is arguable that the members of Congress relied upon nothing other than their own negative reactions, fears and prejudices in fashioning the list of excluded classes."); L. Camille Hebert, Transforming Transsexual and Transgender Rights, 15 WM. \& MARY J. WOMEN \& L. 535, 540 (2009) (stating that the amendment excluding transgender-related conditions "appears to have been motivated by an attempt to appease conservative members of Congress who saw the ADA as favoring individuals whose 'life- 
cluding gender identity disorder and several other stigmatized medical conditions $^{33}$ from the $\mathrm{ADA}$, Armstrong expressed concern with "provid[ing] a protected legal status to somebody who has such disorders, particularly those who might have a moral content to them or which in the opinion of some people have a moral content." ${ }^{34}$ Helms likewise decried the ADA's curtailment of an employer's right to make judgments about employees based on the employer's "own moral standards" 35 :

If this were a bill involving people in a wheelchair or those who have been injured in the war, that is one thing. But how in the world did you get to the place that you did not even [ex]clude transvestites? . . . What I get out of all of this is here comes the U.S. Government telling the employer that he cannot set up any moral standards for his business . . . . [H] e cannot say, look I feel very strongly about people who engage in sexually deviant behavior or unlawful sexual practices. $^{36}$

styles' they did not approve of at the expense of those with religiously-motivated reasons for not wanting to hire those persons"); Kari E. Hong, Categorical Exclusions: Exploring Legal Responses to Health Care Discrimination Against Transsexuals, 11 COLUM. J. Gender \& L. 88, 117-18, 122-23 (2002) (discussing the legislative history of the ADA's transgender exclusions).

33. In addition to "transvestism, transsexualism, . . . [and] gender identity disorders not resulting from physical impairments," the ADA excludes the following medical conditions from its definition of disability: "pedophilia, exhibitionism, voyeurism . . . or other sexual behavior disorders"; "compulsive gambling, kleptomania, or pyromania"; and "psychoactive substance use disorders resulting from current illegal use of drugs." 42 U.S.C. $\int 12211(b)(2012)$.

34. 135 CONG. REC. 19,853 (1989); see also 135 CONG. ReC. 19,896 (1989) (statement of Sen. Rudman) ("[A] diagnosis of certain types of mental illness is frequently made on the basis of a pattern of socially unacceptable behavior and lacks any physiological basis. In short, we are talking about behavior that is immoral, improper, or illegal and which individuals are engaging in of their own volition, admittedly for reasons we do not fully understand . . . . [P] eople must bear some responsibility for the consequences of their own actions."); Barry et al., supra note 32, at 574-76 (stating that "[i]n addition to the direct evidence of moral animus in the ADA's legislative history, indirect evidence of moral animus abounds in the structure of the transgender exclusions" and the "practical effect" of such exclusions).

35. 135 CONG. REC. 19,864 (1989).

36. Id. Significantly, this was not the first time that Senator Helms attempted to exclude transgender people from a civil rights law. In support of his opposition to the 1987 Civil Rights Restoration Act, he posed this question:

[D]o we really want private institutions, particularly schools and day care centers to be prohibited from refusing to hire a transvestite because some Federal court 
For well over twenty-five years, the Armstrong-Helms amendment effectively closed the door to ADA protections for transgender people, who eschewed disability rights law in favor of sex discrimination protections.

\section{BLATT V. CABELA'S RETAIL, INC. AND THE IMPORTANCE OF ADA COVERAGE OF GENDER DYSPHORIA}

Although Gavin Grimm understandably did not challenge his discrimination under the ADA, other transgender litigants have done so despite the ADA's transgender exclusions. ${ }^{37}$ In 2014, a transgender woman named Kate Lynn Blatt, who was diagnosed with gender dysphoria, experienced discrimination while working at Cabela's Retail, a private sporting goods store. ${ }^{38}$ She was required to wear a nametag bearing the name "James" until she provided documentation that her name and gender marker had been legally changed. ${ }^{39}$ She was required to work in a secluded part of the store. ${ }^{40}$ She was subjected to harassment by other employees who called her a host of derogatory names, including "ladyboy," "he/she," "sinner," "fag," and "freak." ${ }^{11}$ And she was prohibited from using the female bathroom. After initially suggesting that she use the

may find that this violates the transvestite's civil rights to wear a dress and to wear foam, that sort of thing? Do we really want to prohibit these private institutions from making employment decisions based on moral qualifications?

Barry et al., supra note 32, at 528 (citing 134 CONG. REC. 4235 (1988)).

And in 1988, Helms proposed an amendment to the Fair Housing Amendments Act to exclude "transvestites" both from the Fair Housing Act and the Rehabilitation Act of 1973. The amendment passed. See Duffy, supra note 32, at 16-32 (discussing Helms's exclusion of "transvestites" from the Fair Housing Act and Rehabilitation Act). According to Helms, the exclusion amounted to "a little common sense . . . . [I]t should be clear to the courts that Congress does not intend for transvestites to receive the benefits and protections that is [sic] provided for handicapped individuals." Barry et al., supra note 32, at 529 (citing 134 CoNG. REC. 19,711-51 (1988)).

37. See infra notes $38-45,83-84,87$ and accompanying text (discussing three cases challenging gender dysphoria discrimination).

38. Blatt v. Cabela's Retail, Inc., No. 5:14-CV-04822, 2017 WL 2178123, at *2 (E.D. Pa. May 18, 2017).

39. Plaintiff's Memorandum of Law in Opposition to Defendant's Partial Motion to Dismiss Plaintiff's First Amended Complaint at 4, Blatt, 2017 WL 2178123 (E.D. Pa. Jan. 20, 2015) (No. 5:14-CV-04822) [hereinafter Blatt Mem. Opp].

40. Complaint \& Jury Demand 9 T 23-24, Blatt, 2017 WL 2178123 (E.D. Pa. Aug. 15, 2014) (No. 5:14-CV-04822) [hereinafter Blatt Complaint].

41. Blatt Mem. Opp., supra note 39 , at 5 . 
restroom at a Dunkin' Donuts across the street, her employer eventually allowed her to use the single-sex "family" restroom at the front of the store. ${ }^{42}$

In 2014, Blatt sued in federal district court in the Eastern District of Pennsylvania, alleging discrimination under both Title VII of the Civil Rights Act and the ADA. ${ }^{43}$ When Cabela's moved to dismiss the ADA claim based on the ADA's transgender exclusions, Blatt did something that no litigant had ever done before-she argued that the exclusions violate the Equal Protection Clause. ${ }^{44}$ Driven by "a bare congressional desire to harm" transgender people, Blatt alleged, Congress excluded from the ADA medical conditions closely associated with such people. ${ }^{45}$ In so doing, Congress deprived transgender people of the unique protections of the ADA (namely, reasonable accommodations) and also stigmatized them as unworthy of civil rights protections. ${ }^{46}$

In an amicus brief, six state and national transgender rights organizations advanced a separate, statutory argument: the ADA's exclusion of "gender identity disorders" does not apply to gender dysphoria, which is a distinct diagnosis with physical roots - not a disorder of identity. ${ }^{47}$ Therefore, amici argued, gender dysphoria is not the equivalent of gender identity disorder as Congress understood it in 1992 or any of the other related conditions excluded from the ADA.

Shortly after this amicus brief was filed, the U.S. Department of Justice under Attorney General Loretta Lynch filed a Statement of Interest that reached the same result as amici, although by slightly different means. Gender dyspho-

42. Id. at 6 .

43. Blatt Complaint, supra note 40, at $91-2$.

44. Blatt Mem. Opp., supra note 39, at 2-3.

45. Id. at 2 (quoting Dep't of Agriculture v. Moreno, 413 U.S. 528 (1973)).

46. See $i d$. at 3 (" $[\mathrm{T}]$ he $\mathrm{ADA}$ isolates, segregates, and injures those transgender individuals that the ADA should protect."); $c f$. Plaintiff's Memorandum of Law in Response to This Court's Order Dated July 28, 2015 at 8-9, Blatt v. Cabela's Retail, Inc., No. 5:14-CV-4822-JFL, 2017 WL 2178123 (E.D. Pa. Aug. 21, 2015) (discussing the ADA's "unique" reasonable accommodation mandate, which is not shared by Title VII). In their amicus brief, six state and national transgender rights organizations echoed these twin themes, arguing that removal of the ADA's transgender exclusions "would provide sorely needed, comprehensive antidiscrimination protection to transgender people" and "would also eliminate a source of blatant, legallysanctioned prejudice against them." Blatt Amicus Brief, supra note 26, at 3.

47. Blatt Amicus Brief, supra note 26, at 12-15 (arguing that gender dysphoria differs from gender identity disorders based on its name, diagnostic criteria, organization within the DSM, and recent scientific studies strongly suggesting that physical conditions-hormonal and possibly genetic - contribute to gender incongruence and thus, gender dysphoria). Although amici explicitly agreed with Blatt's constitutional argument, $i d$. at $2 \mathrm{n} .7$, the amicus brief advanced a statutory argument as an alternative to deciding the constitutional question. 
ria is not distinct from gender identity disorder, DOJ argued, but emerging science indicates that gender dysphoria results not from a mental impairment but rather from a physical one (i.e., neurological, genetic, and/or hormonal sources).$^{48}$ Therefore, DOJ argued, gender dysphoria is not excluded from the ADA based on the terms of the statute-i.e., gender dysphoria is a gender identity disorder resulting from a physical impairment. ${ }^{49}$

For two years, the parties waited. Finally, on May 18, 2017, the court issued a remarkable decision denying Cabela's motion to dismiss Blatt's ADA claim. ${ }^{50}$ The decision is noteworthy for two reasons. First, and most obviously, the decision is the first to hold that gender dysphoria is not an excluded condition under the ADA. Second, the court employed novel analysis to reach this historic result.

Like amici, the court found that "gender identity disorders" are not the same as "gender dysphoria" and, therefore, gender dysphoria is not excluded from the ADA. ${ }^{51}$ But, unlike amici, the court did not base its decision on the fact that "gender identity disorders" constitute a different, outdated medical diagnosis. Instead, the court concluded that the ADA's transgender-related exclusions do not encompass any medical conditions associated with being transgender. ${ }^{52}$

According to the court, the ADA excludes "two distinct categories" of conditions from its definition of disability: "first, non-disabling conditions that concern sexual orientation or identity", such as "homosexuality" and "bisexuality"; and "second, disabling conditions that are associated with harmful or ille-

48. Second Statement, supra note 12, at 3-6. Significantly, the Department of Justice under Attorney General Jeff Sessions has adhered to this position. See infra note 86 and accompanying text (discussing the DOJ's Statement of Interest in Doe v. Arrisi).

49. Compare Second Statement, supra note 12, at 3, with 42 U.S.C. $\$ 12211$ (b) (excluding "gender identity disorders not resulting from physical impairments") (emphasis added).

50. Blatt, 2017 WL 2178123 , at *4 ("[Gender dysphoria] is not excluded by $\mathbb{S} 12211$ of the ADA, and Cabela's motion to dismiss Blatt's ADA claims on this basis is denied.").

51. See id. at $\star_{2}$ (interpreting "the term gender identity disorders [as used in the $\mathrm{ADA}$ ] . . . narrowly to refer to only the condition of identifying with a different gender, not to encompass (and therefore exclude from ADA protection) a condition like Blatt's gender dysphoria").

52. See id. at * 2 \& n.1 (concluding that the term "gender identity disorders" as used in the ADA does not "align[] with the term's definition in the revised third edition of the American Psychiatric Association's Diagnostic and Statistical Manual of Mental Disorders," nor does the term refer to "a condition like Blatt's gender dysphoria, which goes beyond merely identifying with a different gender and is characterized by clinically significant stress and other impairments that may be disabling"). 
gal conduct," such as pedophilia, pyromania, and kleptomania. ${ }^{53}$ "Gender identity disorders," the court reasoned, fall into the first category. "[G]ender identity disorders," as used in the ADA, "refer to only the condition of identifying with a different gender" -i.e., being transgender. ${ }^{54}$ Like being gay, lesbian, or bisexual, the court reasoned, being transgender is, by itself, not a medical condition and is therefore not a disability under the ADA. ${ }^{55}$

Gender dysphoria, by contrast, is a medical condition. "[A] condition like Blatt's gender dysphoria," the court concluded, "goes beyond merely identifying with a different gender and is characterized by clinically significant stress and other impairments that may be disabling . . . . [Specifically, gender dysphoria] substantially limits her major life activities of interacting with others, reproducing, and social and occupational functioning." 56 Because gender dysphoria has medically significant clinical features, it does not fall into the first category of exclusions with sexual orientation and transgender identity. ${ }^{57}$ In addition, because gender dysphoria is "not associated with harmful or illegal conduct," it does not fall into the second category either. ${ }^{58}$ Accordingly, Blatt's condition "is not excluded by . . . the ADA." 59

Interpreting the ADA to exclude gender dysphoria, the court concluded, would have been inconsistent with the ADA's text by "exclud[ing] from the ADA conditions that are actually disabling but that are not associated with harmful or illegal conduct." ${ }^{\circ 0}$ Such an interpretation would also have been inconsistent with the ADA's remedial purpose as indicated by its legislative histo-

53. Id. at ${ }^{\star} 3 \&$ n.2.

54. Id. at ${ }^{\star} 2$; see $i d$. at ${ }^{\star} 4$ ("[I] it is fairly possible to interpret the term gender identity disorders narrowly to refer to simply the condition of identifying with a different gender . . . .").

55. See id. at ${ }^{\star} 3$ (stating that "the term gender identity disorders . . . belong[s] to the first category described above," i.e., "non-disabling conditions that concern sexual orientation or identity"). The Blatt court's reasoning is supported by the American Psychiatric Association's history of pathologizing both gay identity (by labeling same-sex orientation a disorder until 1973) and transgender identity (by labeling gender incongruence a disorder until 2013). See Judith Butler, Undiagnosing Gender, in TRANSGENDER RIGHTS 276-77 (2006) (discussing the APA's diagnoses of "homosexuality" and "gender identity disorder"). As the court suggests, Congress may well have intended for the ADA to exclude only pathologized identities - not the medical conditions that people with those identities may have.

56. Blatt, 2017 WL 2178123 , at ${ }^{\star} 2,{ }^{\star} 4$.

57. Id. at ${ }^{\star} 3-4$ (distinguishing the ADA's exclusion of "non-disabling conditions that concern sexual orientation or identity" from the ADA's inclusion of "disabling conditions that persons who identify with a different gender may have - such as Blatt's gender dysphoria").

58. Id. at ${ }^{\star} 3$.

59. Id. at ${ }^{\star} 4$.

6o. Id. at ${ }^{\star} 3$. 
ry, "which reveal[ed] that Congress was careful to distinguish between excluding certain sexual identities from the ADA's definition of disability, on one hand, and not excluding disabling conditions that persons of those identities might have, on the other hand." ${ }^{1}$ Indeed, Congress "specifically rejected amendments" that would have prevented "a person who is gay from receiving coverage under the statute if the person had a disability," such as HIV/AIDS. ${ }^{62}$ So, too, with gender identity disorders: Congress did not intend to prevent people who "identify[] with a different gender," i.e., transgender individuals, from receiving coverage under the statute if the person has a medical condition like gender dysphoria. ${ }^{63}$

In sum, the court in Blatt recognized two discrete but sometimes related experiences-one of being transgender, the other of having gender dysphoria. Being transgender is, standing alone, akin to being gay or lesbian; it is not a medical condition and, therefore, does not by itself bring a person under the ADA's protections. ${ }^{64}$ Gender dysphoria, however, is distinct; it is a quintessentially stigmatized medical condition characterized by clinically significant distress associated with being transgender. ${ }^{65}$ Importantly, the court recognized that no principled reason exists for excluding transgender people who experience a medical condition associated with that identity from securing protections under the ADA. ${ }^{66}$

The court's decision is consistent with contemporary medical standards and represents a major step forward for transgender people. While not all transgender people experience clinically significant distress, the fact that many

61. Id. at ${ }^{\star} 3$ (emphasis added).

62. Id. at ${ }^{\star} 3$ n.3 (quoting H.R. Rep. 101-485, at 76 (1990)).

63. Id. at ${ }^{\star} 4$. According to the Blatt court, interpreting the ADA to exclude gender dysphoria would also have been inconsistent with the constitutional avoidance canon of statutory construction. Because the court's interpretation "allow[ed] the Court to avoid the constitutional questions raised in this case" -i.e., that the exclusion of gender identity disorders violates equal protection - "it [wa]s the Court's duty to adopt it.” Id.

64. See Barry \& Levi, supra note 16.

65. See Breakthrough for Trans Civil Rights Protections, GLAD (May 19, 2017), http://www.glad .org/post/breakthrough-trans-civil-rights-protections [http://perma.cc/247W-W2QQ].

66. See id; see also Patrick Dorrian, Disability Bias Ruling for Transgender Worker: Boon or Blip?, BloOMBERG LAB. \& EMPL. (BNA) (June 1, 2017) ("'When viewed through the prism of disability, judges have less difficulty seeing that the cure' for gender dysphoria is allowing gender-diverse and gender-affirmed people to express themselves through which bathroom they use, how they dress, and how they otherwise present themselves to the public and at work . . . . [Disability law] also helps judges "understand the underlying medical condition [of gender dysphoria] and that trans people are normal." (quoting Christine Duffy, Senior Staff Attorney, Pro Bono Partnership)). 
do should not be ignored - particularly by our civil rights laws. ${ }^{67}$ The Blatt decision goes a long way in recognizing this, righting a decades-long wrong that deprived transgender people of the opportunity to challenge bias and stigma associated with a medical condition.

The strategy of pursuing disability protections for transgender people has received criticism from some transgender rights advocates. ${ }^{68}$ Challenges to this approach come in two basic varieties. The first is that, by recognizing gender dysphoria as a medical condition, ADA claims pursued by transgender litigants legitimate the pathologization of transgender identity. This concern ignores the distinction between transgender identity and gender dysphoria. Transgender identity is not a medical condition. ${ }^{69}$ Gender dysphoria, on the other hand, is a medical condition; it is real, serious, and physically incapacitating, and often can only be ameliorated by medical care. ${ }^{70}$ It is also a highly stigmatized medical

67. See Blatt Amicus Brief, supra note 26 , at 18 (stating that, "[b]y maintaining th[e] exclusion" of gender dysphoria, "the ADA perpetuates the very thing it seeks to dismantle: the prejudiced attitudes or ignorance of others and the inferior status that people with disabilities occupy in our society" (internal quotation marks omitted)).

68. See, e.g., Jeannie J. Chung, Identity or Condition?: The Theory and Practice of Applying State Disability Laws to Transgender Individuals, 21 COLUM. J. GENDER \& L. 1, 35-36 (2011); Hébert, supra note 32, at 542-43; S. Elizabeth Malloy, What Best To Protect Transsexuals from Discrimination: Using Current Legislation or Adopting a New Judicial Framework, 32 WOMEN's RTS. L. REP. 283, 316 (2011); Dean Spade, Resisting Medicine, Re/modeling Gender, 18 BERKELEY WOMEN's L.J. 15, 35 (2003). For articles supporting disability rights protection for medical conditions associated with transgender people, see, for example, Katie Aber, When AntiDiscrimination Law Discriminates: A Right to Transgender Dignity in Disability Law, 50 Colum. J. L. \& Soc. Probs. 299, 301 (2017); Barry, supra note 32, at 34-49; Colker, supra note 32, at 34, 50; Duffy, supra note 32, at 16-9 to -10; Adrienne L. Hiegel, Sexual Exclusions: The Americans with Disabilities Act as Moral Code, 94 Colum. L. Rev. 1451, 1479 (1994); Hong, supra note 32, at 93-94; Jennifer L. Levi \& Bennett H. Klein, Pursuing Protection for Transgender People Through Disability Laws, in Transgender Rights 74-83 (Paisley Currah et al. eds., 2006); Zach Strassburger, Disability Law and the Disability Rights Movement for Transpeople, 24 YALE J. L. \& FEMINISM 337, 338 (2012).

69. Compare DSM-5, supra note 14 , at 458 ("Gender dysphoria should be distinguished from simple nonconformity to stereotypical gender role behavior by the strong desire to be of another gender than the assigned one and by the extent and pervasiveness of gender-variant activities and interests."), with id. at 452 ("The condition is associated with clinically significant distress or impairment in social, occupational, or other important areas of functioning."), and id. at 453 (stating that, in addition to marked incongruence, "[ $\mathrm{t}]$ here must also be evidence of distress about this incongruence").

70. See DSM-5, supra note 14, at 451 ("Although not all [transgender] individuals will experience distress as a result of [gender] incongruence, many are distressed if the desired physical interventions by means of hormones and/or surgery are not available."); $i d$. at 454 ("Adolescents and adults with gender dysphoria before gender reassignment are at increased risk for suicidal ideation, suicide attempts, and suicides. After gender reassignment, adjustment may 
condition that engenders fear and discomfort in others - the very type of condition that Congress had in mind when it passed the ADA. ${ }^{71}$ Because the ADA was intended to redress prejudice associated with stigmatized medical conditions, people who experience such prejudice ought to pursue these protections, not avoid them.

The second concern is that, unlike sex discrimination law, ADA coverage of gender dysphoria might brand transgender people as incapable of functioning. This concern misunderstands disability rights law. The ADA has always embodied the "social model" of disability: the idea that negative reactions to medical conditions - not the conditions themselves - "disable."72 For nearly twenty years, the Supreme Court effectively ignored the social model, articulating instead a "medical model" of disability: the idea that disability results from severely limiting medical conditions. ${ }^{73}$ But in 2008 , with tremendous bipartisan support, Congress amended the ADA to clarify its original intent that "disability" should be broadly construed to protect virtually everyone who experiences discrimination based on a medical condition - real or perceived, functionally

vary, and suicide risk may persist.”); see also WORLD PROF'L ASS'N FOR TRANSGENDER HeAlth, StandardS OF CARE 5 (7th ed., 2012), http://admin.associationsonline.com /uploaded_files/140/files/Standards\%20of\%20Care,\%20V7\%2oFull\%2oBook.pdf [http:// perma.cc/EV78-4W43] ("Gender dysphoria can in large part be alleviated through treatment.").

71. See Levi \& Klein, supra note 68, at 88-89; see, e.g., 42 U.S.C. $\$ 12101(a)(2)$ (2012) (finding that "society has tended to isolate and segregate individuals with disabilities"); $i d$. $\$$ 12101(a)(6) (finding that "people with disabilities, as a group, occupy an inferior status in our society"); H.R. REP. NO. 101-485 pt. 3, at 30-31 (discussing ADA coverage of "a person who is rejected from a job because of the myths, fears, and stereotypes associated with disabilities"); Samuel R. Bagenstos, Subordination, Stigma, and Disability, 86 VA. L. REV. 397, 437, 445 (2000) (stating that the ADA protects those whose impairments are "stigmatized," that is, those who "differ too much from a socially defined "norm," such that they are considered "abnormal or defective in mind or body"); cf. Sch. Bd. of Nassau Cnty. v. Arline, 48o U.S. 273, 284 (1987) (stating that "the basic purpose" of ADA's predecessor, Section 504 of the Rehabilitation Act, "is to ensure that handicapped individuals are not denied jobs or other benefits because of the prejudiced attitudes or the ignorance of others," and stating that "society's accumulated myths and fears about disability and disease are as handicapping as are the physical limitations that flow from actual impairment").

72. See, e.g., SAmuel R. Bagenstos, LaW And the Contradictions of the Disability Rights MOVEMENT 18-20 (2009) (discussing the social model of disability); Kevin Barry, Toward Universalism: What the ADA Amendments Act of 2008 Can and Can't Do for Disability Rights, 31 BERKELEY J. EMP. \& LAB. L. 203, 211-12 (2010) (same).

73. See BAGENSTOS, supra note 72, at 18-20 (discussing the medical model of disability); Barry, supra note 72 , at 210-11 (same). 
limiting or not. ${ }^{74}$ As a result, many treatable medical conditions that would be functionally limiting in the absence of such treatment-including epilepsy, diabetes, major depressive disorder, bipolar disorder, post-traumatic stress disorder, and obsessive compulsive disorder-are now presumed to be disabilities under the amended law. ${ }^{75}$ Add to this the ADA's coverage of minor medical conditions that are not typically thought of as "disabilities," such as skin graft scars, and it is clear that ADA coverage is not tied to an inability to function. ${ }^{76}$

Given the breadth of the ADA's definition of disability, there is no reason to resist categorizing gender dysphoria as a disability. Indeed, the continued exclusion of gender dysphoria, along with eight conditions that involve "harmful or illegal conduct," ${ }^{, 7}$ is more likely to exacerbate - not reduce - the stigma asso-

74. See Barry, supra note 72 , at 278 (discussing "nearly universal nondiscrimination protection under the 'regarded as' prong" of the ADA's definition of disability and reasonable accommodation protection for a "vastly expanded" class of people); Michelle A. Travis, Impairment as Protected Status: A New Universality for Disability Rights, 46 GA. L. REV. 937, 952-55 (2012).

75. See, e.g., 29 C.F.R. $\$ \$ 1630.2(j)(3)$ (ii)-(iii) (2016) (listing impairments that, "[g]iven their inherent nature . . . will, as a factual matter, virtually always be found to impose a substantial limitation on a major life activity" and including "autism . . . diabetes . . . epilepsy . . . major depressive disorder, bipolar disorder, post-traumatic stress disorder, [and] obsessive compulsive disorder"); 28 C.F.R. $\mathbb{S}$ 35.108(d)(2)(iii)(E)-(K) (2016) (discussing “[p]redictable assessments" of disability).

76. EEOC Interpretive Guidance on Title I of the Americans with Disabilities Act, 29 C.F.R. $\$ 1630$ app. (2012) ("[I]f an employer refused to hire an applicant because of skin graft scars, the employer has regarded the applicant as an individual with a disability.”); see also Restoring Congressional Intent and Protections Under the Americans with Disabilities Act: Hearing on S. 1881 Before the S. Comm. on Health, Educ., Labor, \& Pensions, 11oth Cong. (2007) (statement of Chai R. Feldblum, Professor of Law, Georgetown University Law Center) ("This [hearing] room is filled with people with disabilities who want Congress to pass [the ADA Amendments Act]. They don't believe this bill sets back their cause. Why not? Because they understand there is no set of 'truly disabled' people and then all the rest of us. We all exist along a spectrum of abilities. It is true that many of us might never experience discrimination because of our physical or mental impairments, while others of us may experience significant discrimination. But that is not because some of us are truly disabled and others are not. It is because of the type of discrimination that some of us will suffer, and others of us will not. There is no 'us' and 'them.'”); Kevin M. Barry, Exactly What Congress Intended?, 17 EMP. RTS. \& EMP. POL'Y J. 5, 27-31 (2013) (listing a broad range of impairments that courts have found to be disabilities under the amended law); Cass R. Sunstein, Caste and Disability: The Moral Foundations of the ADA, 157 U. PA. L. REV. PENNUMBrA 21, 26 (2008) (responding to Elizabeth F. Emens, Integrating Accommodation, 156 U. PA. L. REV. 839 (2008) by arguing that there is no "sharp dichotomy" between "those who are able and those who are not . . . . [T] here is a continuum here . . . [T] $[\mathrm{T}$ he purpose of the ADA, rightly conceived, is to break down distinctions that have their current force only because of social practices that have been so taken for granted that they are often unseen as practices at all.”).

77. Blatt v. Cabela's Retail, Inc., No. 5:14-CV-04822, 2017 WL 2178123, at ${ }_{3}$ (E.D. Pa. May 18, 2017). 
ciated with gender dysphoria. For these reasons, and notwithstanding wellintentioned concerns, the overwhelming consensus among transgender rights advocates is strongly in favor of ADA coverage of gender dysphoria. ${ }^{78}$

\section{A NEW PATH: GENDER DYSPHORIA DISCRIMINATION}

Blatt marks the beginning of a new way forward toward securing legal protections for transgender people through disability rights law. ${ }^{79}$ Transgender litigants who have gender dysphoria, who once had gender dysphoria and have successfully treated it (for example, by living part time or full time in their desired gender role, undergoing hormone therapy, having surgery, or some combination), or who are erroneously perceived as having gender dysphoria (i.e., those who do not experience distress but who are transgender)-might now consider bringing ADA claims. ${ }^{80}$

The ADA, with its distinct structure and scope, is well-suited to combat discrimination against transgender people who have, had, or are perceived as

78. See, e.g., Brief for Bay Area Lawyers for Individual Freedom et al. as Amici Curiae in Opposition to Defendants' Motion to Dismiss at vii-xii, Doe v. Arrisi, No. 3:16-CV-o8640 (D.N.J. Feb. 24, 2017) (arguing in support of ADA coverage of Gender Dysphoria on behalf of: Bay Area Lawyers for Individual Freedom, Gay \& Lesbian Advocates and Defenders, Gender Justice, Intersex \& Genderqueer Recognition Project, The LGBT Bar Association of New York, National Center for Lesbian Rights, The National Center for Transgender Equality, National LGBTQ Bar, National LGBTQ Task Force, Transgender Legal Defense \& Education Fund, Trans United, and Whitman-Walker Clinic, Inc.); see also supra note 68 and accompanying text (discussing the debate surrounding disability rights protections for medical conditions associated with transgender people).

79. See, e.g., Dorrian, supra note 66 (stating that Blatt "should be a further signal to corporate America that 'a tipping point has come' in the march toward LGBT workplace rights" (quoting Christine Duffy, Senior Staff Attorney, Pro Bono Partnership)); Barry \& Levi, supra note 64 ("The seeds of prejudice in the ADA have sown the future of transgender rights advocacy."). In the eloquent words of Senior Judge Andre Davis, Blatt's case, like Gavin Grimm's, "is part of a larger movement that is redefining and broadening the scope of civil and human rights so that they extend to a vulnerable group that has traditionally been unrecognized, unrepresented, and unprotected." G.G. ex rel. Grimm v. Gloucester Cty. Sch. Bd., 853 F.3d 729, 730 (4th Cir. 2017) (Davis, J., concurring in order vacating preliminary injunction). By challenging the ADA's transgender exclusions, Blatt rightly stands with "brave individuals Dred Scott, Fred Korematsu, Linda Brown, Mildred and Richard Loving, Edie Windsor, and Jim Obergefell, to name just a few - who refused to accept quietly the injustices that were perpetuated against them." Id.

80. Compare, Blatt, $2017 \mathrm{WL} 2178123$, at ${ }^{\star} 4$ (holding that the ADA does not exclude gender dysphoria from definition of disability), with 42 U.S.C. $\mathbb{S S}$ 12102(1), (3) (2012) (defining disability to include past or present substantially limiting impairments, as well as adverse treatment based on any impairment - real or perceived, limiting or not). 
having gender dysphoria, for two reasons. First, unlike sex discrimination law, the ADA defines discrimination to include not only disparate treatment and disparate impact, but also the failure to provide "reasonable accommodations" in the workplace and to "reasonably modify" discriminatory policies, such as those governing restroom usage, dressing, and grooming standards. ${ }^{81}$ Second, unlike Title VII and Title IX, the ADA is comprehensive; its legal protections extend beyond employment and education to public accommodations and state and local government benefits and services. ${ }^{82}$

Accordingly, in addition to challenging employment discrimination under the $\mathrm{ADA}$, as Blatt did, transgender litigants may consider challenging gender dysphoria discrimination in a range of other contexts. For example, in November 2016, in Doe v. Arrisi, a woman with gender dysphoria sued the state of New Jersey in federal district court over a state law-shared by a majority of states - that requires proof of gender confirmation surgery in order to change the gender marker on one's birth certificate. ${ }^{83}$ Requiring a person with gender dysphoria to undergo medical treatment that is unnecessary, medically contraindicated, or too costly, she argues, not only violates the Due Process and Equal Protection Clauses but also constitutes disability discrimination under the ADA.$^{84}$ Significantly, after New Jersey invoked the ADA exclusion as grounds for dismissing the plaintiff's ADA claim, ${ }^{85}$ the Department of Justice under Attorney General Jeff Sessions filed a Statement of Interest supporting ADA cover-

81. See 42 U.S.C. $\ 12112(b)(5)$ (reasonable accommodations in employment); id. $\$ 12182(\mathrm{~b})(2)(\mathrm{A})(\mathrm{ii})$ (reasonable modifications in public accommodations); 28 C.F.R. $\mathbb{S} 35.130(\mathrm{~b})(7)(\mathrm{i})$ (reasonable modifications in government benefits and services).

82. See 42 U.S.C. $\$ 12101$ et seq. (prohibiting disability discrimination in employment, state and local government benefits and services, and public accommodations). By contrast, there is no federal statute that prohibits sex discrimination in either public accommodations or government benefits and services. Titles II and VI of the Civil Rights Act prohibit discrimination in public accommodations and federally-funded government programs and activities, respectively, based on "race, color, religion, or national origin" - not sex. See 42 U.S.C. $\$$ 2oooa (Title II); id. $\$$ roood (Title VI).

83. Complaint 99 2-3, 10, Arrisi, No. 3:16-CV-o8640 (D.N.J. Nov. 18, 2016) [hereinafter Arrisi Complaint]; see also Changing Birth Certificate Sex Designations: State-By-State Guidelines, LAMBDA LEGAL, http://www.lambdalegal.org/know-your-rights/article/trans -changing-birth-certificate-sex-designations [http://perma.cc/N83T-PV4Q] (compiling state laws regarding changing gender marker on birth certificates).

84. Arrisi Complaint, supra note 83 , at 9 \ 45-49.

85. Brief for Defendants in Support of Their Motion to Dismiss at 27, Arrisi, No. 3:16-CVo8640 (D.N.J. Dec. 28, 2016) (invoking the ADA exclusion). 
age for gender dysphoria and reiterating its position in Blatt that gender dysphoria that results from a physical impairment is not excluded by the ADA. ${ }^{86}$

Transgender litigants may also consider bringing ADA claims to challenge: (1) state prison policies that deny transgender prisoners access to proper medical care and gender-appropriate facilities and programs, as a formerly incarcerated transgender woman in Connecticut has done $;^{87}$ (2) laws like North Carolina's H.B. ${ }^{88}$ as well as the actions of private businesses, which deny people with gender dysphoria access to gender-appropriate facilities, including bathrooms $;{ }^{89}$ and (3) policies like those at issue in G.G. that deny people with gender dysphoria access to gender-appropriate facilities and other services in public and private schools. ${ }^{90}$

In addition to the $\mathrm{ADA}$, transgender litigants may consider invoking the protections of two other federal disability rights statutes that contain

86. Statement of Interest of the United States at 2-3, Arrisi, No. 3:16-CV-o8640 (D.N.J. July 17, 2017) (citing 42 U.S.C. $\$ 12211(b)(1)$ ) (“[B]ecause Plaintiff has alleged that her GD resulted from a 'physical impairment,' . . . by definition she has alleged that she falls within the statutory protections of the ADA.”). Twelve transgender rights and transgender health organizations have filed an amicus brief in support of the Plaintiff that addresses the statutory and equal protection arguments in favor of ADA protection for gender dysphoria. See Bay Area Lawyers Amici, supra note 78, at 2-3.

87. In November 2016, in Doe v. Dzurenda, a young woman with Gender Dysphoria sued the state of Connecticut in federal district court for, among other things, placing her in solitary confinement in a gender-inappropriate facility, denying her the ability to participate in programs with peer groups that aligned with her gender identity, using the wrong name and pronoun when referring to her, and prohibiting her from wearing gender-appropriate clothing and accessories. These actions, she alleges, violated not only the Eighth Amendment and the Due Process Clause, but also the ADA, Rehabilitation Act, and other federal statutes that protect prisoners. See Complaint, $\Upsilon \Upsilon$ 122-222, Doe v. Dzurenda, No. 3:16-CV-01934 (D. Conn. Nov. 23, 2016) [hereinafter Dzurenda Complaint]. The State of Connecticut has invoked the ADA exclusion. Defendants' Memorandum In Support of Motion to Dismiss at 41-43, Dzurenda, No. 3:16-CV-01934 (D. Conn. May 1, 2017).

88. See Richard Fausset, Bathroom Law Repeal Leaves Few Pleased in North Carolina, N.Y. TimES (Mar. 30, 2017), http://www.nytimes.com/2017/03/30/us/north-carolina-senate-acts-to -repeal-restrictive-bathroom-law.html [http://perma.cc/JZX6-C8HH] (discussing North Carolina's House Bill 2, which "restricted the ability of municipalities to enact antidiscrimination policies and required transgender people in government and public buildings to use the bathroom that corresponds with the gender on their birth certificate").

89. See Transgender People and Access to Public Accommodations, NAT'L CTR. FOR TRANSGENDER EQUALITY (Sept. 2014), http://www.transequality.org/sites/default/files/docs/kyr/Public Accommodations_September2014.pdf [http://perma.cc/GS9S-YVX 3 (discussing the "patchwork of state and local laws" prohibiting discrimination against transgender people in public accommodations and the lack of federal law prohibiting such discrimination).

9o. See supra note 4 and accompanying text (discussing the public school's refusal to permit Gavin Grimm to use gender-appropriate bathroom). 
transgender exclusions: the Rehabilitation Act of 1973, which prohibits disability discrimination by federal agencies and recipients of federal funds, and the Fair Housing Act, which prohibits disability discrimination in housing sales, rentals, and financing. ${ }^{91}$ Because the Rehabilitation Act excludes from its definition of "disability" the same conditions as the $\mathrm{ADA},{ }^{92}$ the interpretation of the latter by the Blatt court, Blatt amici, and the Trump Administration itself should apply with equal force to the former. Gender dysphoria is therefore not excluded from the protection of the Rehabilitation Act. ${ }^{93}$ This means that adverse action taken against transgender people by federal agencies and recipients of federal funds (including state agencies that receive federal funding) may well constitute disability discrimination in violation of the Rehabilitation Act. ${ }^{94}$

91. Compare 29 U.S.C. $\$ \$ 705(20)(F)(i), 794$ et seq. (2012) (prohibiting federal agencies and recipients of federal funds from discriminating based on disability, and excluding, inter alia, "transsexualism" and "gender identity disorders not resulting from physical impairments" from definition of disability), with 42 U.S.C. $\$ 3601$ et seq. (2012) (prohibiting housing providers and lending institutions from discriminating based on race, color, religion, sex, national origin, familial status, or disability, and excluding "transvestites" from definition of disability through a statutory note to $\$ 3602$ ). Because the Fair Housing Act prohibits discrimination based on sex as well as disability, transgender individuals can currently seek protection under the Fair Housing Act "based on non-conformity with gender stereotypes." Ending Housing Discrimination Against Lesbian, Gay, Bisexual, and Transgender Individuals and Their Families, Enriching and Strengthening Our Nation, U.S. DeP'T Housing \& URb. Dev., http://portal.hud.gov/hudportal/HUD?src=/program_offices/fair_housing_equal_opp

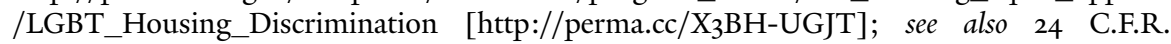
$\mathbb{S}$ 5.105-06 (prohibiting discrimination based on "gender identity" under Fair Housing Act). Disability coverage would provide transgender individuals with a second path to recovery under the Fair Housing Act as well as additional protections not afforded in the sex discrimination context, namely, reasonable accommodations. See, e.g., 42 U.S.C. $\mathbb{S} 3604(\mathrm{a})(3)(\mathrm{B})$ (discussing "reasonable accommodations in rules, policies, practices, or services" for people with disabilities).

92. After excluding "transsexualism" and "gender identity disorders not resulting from physical impairments" from the ADA in 1990, Congress passed an identical exclusion to the Rehabilitation Act two years later. See 29 U.S.C. $\$ 705(20)(F)(i)$ (excluding "transsexualism" and "gender identity disorders not resulting from physical impairments"); H.R. REP. No. 102973, at 158 (1992) (discussing an amendment to the Rehabilitation Act); see also 29 U.S.C. $\mathbb{S} \mathbb{S} 705(20)(\mathrm{B})($ " $[\mathrm{T}]$ he term 'individual with a disability' means, for purposes of [inter alia, Section 504 of the Rehabilitation Act (29 U.S.C. $\$ 794)]$. . . any person who has a disability as defined in [the ADA, as amended by the ADA Amendments Act (42 U.S.C. (12102)].").

93. See supra notes 12, 47-67 and accompanying text (discussing the Blatt decision, the amicus brief in Blatt, and the Trump Administration's Statement of Interest in Doe v. Arrisi, all of which support coverage of gender dysphoria under the ADA as a matter of statutory interpretation).

94. See 29 U.S.C. $\mathbb{S} 794$ et seq. (2012) (prohibiting federal agencies and recipients of federal funds from discriminating based on disability); see, e.g., Dzurenda Complaint, supra note 87, 
It also means that the Rehabilitation Act's affirmative action requirements for people with disabilities should apply to individuals with gender dysphoria. ${ }^{95}$

\section{CONCLUSION}

For over twenty-five years, the ADA deprived transgender people of its protections by excluding "gender identity disorders." As a result of this exclusion, transgender litigants have not invoked the ADA's protections, relying instead on sex discrimination law. ${ }^{96}$ But this is changing. In Blatt v. Cabela's Retail, the Eastern District of Pennsylvania held that being transgender is not a medical condition, but gender dysphoria is - and it is therefore not excluded from the ADA. For the first time ever, a court has ruled that people who have, had, or are perceived as having gender dysphoria are covered by the ADA. The Department of Justice under both the Obama and Trump Administrations, moreover, has reached the same result - albeit by different reasoning.

Blatt's historic holding will reverberate beyond the facts of that case, setting the stage for ADA challenges to a broad range of discrimination against transgender people. In the employment and education contexts, the ADA will supplement the protections provided by sex discrimination law through its unique requirement of reasonable accommodation. Where sex discrimination law does not reach, such as in the prisoner rights and public accommodations contexts, the $\mathrm{ADA}$ can fill important gaps, providing a remedy to many of the problems created by anti-transgender laws and policies. The door is also open for transgender litigants to begin challenging gender dysphoria discrimination under the Rehabilitation Act and the Fair Housing Act. Notwithstanding the well-intentioned concerns of some transgender rights advocates, disability rights coverage of gender dysphoria does not pathologize transgender identity or brand transgender people as incapable of functioning. Rather, it provides a legal remedy that should never have been denied: comprehensive antidiscrimination protection for a serious, stigmatized medical condition.

T 213 (alleging gender dysphoria discrimination by the Connecticut Department of Children and Families under the Rehabilitation Act, and stating that the agency "accepts federal financial assistance").

95. See 29 U.S.C. $\ 791$ (affirmative action by federal government); $i d . \$ 793$ (affirmative action by federal contractors).

96. Notably, transgender litigants have successfully pursued legal protection under state disability laws, the vast majority of which do not exclude gender identity disorders. See Barry et al., supra note 32, at 523-24 (discussing the forty states that do not exclude gender identity disorders from their disability antidiscrimination laws). 
Time will tell how far this new path of legal protection will take transgender people, but one thing is for sure: we are at last moving in the right direction. Disability rights law is finally catching up with medical science to protect the lives and health of transgender individuals.

Kevin Barry is a Professor of Law at Quinnipiac University School of Law and CoDirector of the law school's Civil Justice Clinic. He represented the disability community in support of their successful effort to amend the Americans with Disabilities Act in 2008. Jennifer Levi is a Professor of Law at Western New England University School of Law and the Director of the Transgender Rights Project at GLBTQ Legal Advocates \& Defenders. Levi was co-counsel in the Massachusetts and Connecticut marriage cases that paved the way for marriage equality for same-sex couples nationally. An earlier version of this Essay was delivered at the Harvard Civil Rights-Civil Liberties Law Review Symposium on Transgender Rights in 2017. The authors are grateful to Kate Lynn Blatt and her attorneys, Brian Farrell, Sidney Gold, and Neelima Vanguri, for their outstanding advocacy, and to Kylar Broadus, Erwin Chemerinsky, Christine Duffy, Shannon Minter, Sarah Russell, Scott SkinnerThompson, Harper Jean Tobin, Ilona Turner, and Thomas Ude for thoughtful advice and support.

Preferred Citation: Kevin Barry \& Jennifer Levi, Blatt v. Cabela's Retail, Inc. and a New Path for Transgender Rights, 127 YALE L.J. F. 373 (2017), http://www .yalelawjournal.org/blatt-v-cabelas-retail-inc-and-a-new-path-for-transgender -rights. 